\title{
Visible light induced Knoevenagel condensation: A clean and efficient protocol using aqueous fruit extract of tamarindus indica as catalyst
}

\author{
Rammohan Pal* \\ Department of Chemistry, Acharya Jagadish Chandra Bose College, Kolkata 700 020, West Bengal, India \\ *Corresponding author E-mail: pal_rammohan@yahoo.com
}

\begin{abstract}
Visible light induced a highly efficient and environmentally-friendly Knoevenagel condensation of various aliphatic and aromatic aldehydes with malononitrile has been achieved in excellent yield in presence of aqueous tamarind juice. The tamarind juice could be simply prepared from unripe fruit of Tamarindus indica in water and the reactions go to completion within 2-7 min. A plausible mechanism of light induced Knoevenagel condensation reaction catalyzed by tamarind juice was discussed.
\end{abstract}

Keywords: Knoevenagel condensation, visible light, aqueous tamarind juice, aldehydes, malononitrile.

\section{Introduction}

Knoevenagel condensation [1] is one of the most important and widely employed methods for the formation of carboncarbon bonds [2-4]. It has been used for the preparation of a wide range of substituted alkenes, and for the synthesis of intermediate such as coumarin derivatives which are useful in perfumes, cosmetics and bioactive compounds [5-8]. In addition, Knoevenagel condensation products exhibit inhibition of antiphosphorylation of EGF-receptor and antiproliferative activity [9]. Due to their importance from a pharmacological, industrial and synthetic point of view a large number of methods for the Knoevenagel condensation have been reported using various Lewis acids/bases [10-14], microwave assisted reaction [15-17], ultrasound irradiation [18,19], biotechnology-based approach [20,21], solid phase [22,23], ionic liquid [24-26] or using green solvent like water [27-29], and grindstone method under solvent-free condition [30-32]. It is noteworthy to observe that all these protocols have some drawbacks, such as use of expensive catalyst, high thermal conditions, disposal of toxic solvents and catalyst, long reaction time often pose a problem.

In the past two decades, classical organic chemistry had been rewritten around new approaches that search for products and processes in the chemical industry that are environmentally acceptable [33]. Therefore, to address depletion of natural resources and preservation of ecosystem is just urgent to develop so called "greener technologies" to make chemical agents for wellbeing of human health [34].

An attractive area in organic synthesis involves photochemical reactions particularly using visible light in environmentfriendly solvent like water or aqueous ethanol and is generally considered as a clean and green procedure. This type of photo-activation of substrate very often minimizing the for- mation of byproducts and requires much lesser time corresponds to thermal methods and for this reason, photochemical reactions occupy an interesting position and excellent reviews/paper have been published [35-40]. The use of water as a reaction medium is not only inexpensive and environmentally benign but also provides completely different reactivity [41]. It has been suggested that the effect of water on organic reaction may be due to the high internal pressure exerted by a water solution which results from the high cohesive energy of water [42].

In literature, a number of organic reactions using natural catalysts such as clay [43-46], natural phosphates [47-49], animal bone [50], and various fruit juices are reported. Due to acidic nature aqueous fruit juice like lemon [51-57], pineapple [58], [59], coconut [60], Acacia concinna [61], Sapindus trifolistus [62] and Tamarindus indica [63] fruit has been found to be a suitable replacement for various homogeneous acid catalysts.

Tamarind (Tamarindus indica) is grown extensively in Africa, South Asia, Northern Australia, South East Asia, Taiwan and China. Tamarind has long been one of the most popular of the non-citrus tropical and subtropical fruits, largely because of its attractive flavor and refreshing sugar-acid balance. The main ingredients [64] of 100 gm of pulp of tamarind fruit contain water $(15-30 \%)$, protein $(2-9 \%)$, fat $(0.5$ $3 \%)$, total carbohydrate (56-82\%), edible fiber $(2.2-18.3 \%)$, ash $(2.1-3.3 \%)$, calcium (81-466 mg), phosphorous (86$190 \mathrm{mg}$ ), iron (1.3-10.9 mg), sodium (23-28 mg), potassium $(62-570 \mathrm{mg})$. It also contains $41-58 \%$ sugars of which 25 $45 \%$ is in the form of reducing sugars and $16 \%$ is in the form of non-reducing sugars and tartaric acid is (8-18\%) and ascorbic acid is (3-9 mg). The composition of the tamarind fruit juice varies with geographical, cultural and seasonal harvesting and processing. An aqueous extract of tamarind fruit juice is acidic due to presence of tartaric acid and ascorbic acid and acidity percentage is $50.3 \%$ and hence it will be 
work as an acid catalyst for condensation of aldehydes and active methylene compound.

\section{Experimental}

General: All reactions were run in dried glassware. Reagents were purchased (Spectrochem or SRL or Sigma-Aldrich) and used without further purification. Melting points were determined on a Kofler block and uncorrected. Reactions were irradiated in a $200 \mathrm{~W}$ tungsten lamp (Philips India Ltd). $1 \mathrm{H}$ and $13 \mathrm{C}$ NMR and spectra were obtained in $\mathrm{CDCl} 3$ or DMSO-d6 on Bruker AV-300 (300 MHz) spectrometers using TMS as an internal standard. Mass spectra were acquired on a QTOF micro mass spectrometer. Analytical samples were dried in vacuo at room temperature. The carbon, hydrogen and nitrogen percentages in synthesized products were analyzed by Perkin-Elmer 2400 series II C, H, N analyzers. Thin layer chromatography was carried out on silica gel G.

\subsection{Preparation of aqueous extract of tamarind juice}

The raw tamarind fruits were purchased from the local market. The upper shell of unripped fruit and its inner grain were removed. The hard green material (pulp, $10 \mathrm{~g}$ ) was boiled with water $(50 \mathrm{~mL})$, cooled and it was centrifuged using micro centrifuge (REMI RM-12C). The clear portion of the aqueous extract $(\mathrm{pH}=3)$ of the tamarind fruits was used as catalyst for the reactions.

\subsection{General method for the condensation of alde- hydes with malononitrile}

Different aromatic and aliphatic aldehydes (1a-v) $(10 \mathrm{mmol})$ or $(1 \mathbf{w})(5 \mathrm{mmol})$, malononitrile $(10 \mathrm{mmol})$, and aqueous tamarind juice $(5 \mathrm{~mL}, \mathrm{pH}=3)$ were taken in a round bottomed flask and irradiated with a $200 \mathrm{~W}$ tungsten lamp (Philips India Ltd). The reaction time varied from 2-7 min monitored by TLC. Upon completion of the reaction, the reaction mixture was cooled and the crystalline products (3a-t and $\mathbf{3 w}$ ) so obtained was filtered, washed with water and dried in vacuo. In case of $3 \mathbf{u}$ and $3 \mathbf{v}$ the reaction mixture was extracted with ethyl acetate, dried over anhydrous sodium sulphate and chromatographed over silica gel to obtained oily product $\mathbf{3 u}$ v. The Knoevenagel condensation products were isolated in excellent yields in essentially pure form.

\subsection{Spectral data of unknown compounds}

2-(3-Hydroxyphenylmethylene) malononitrile (3a): Yellow crystal, Yield: $92 \%$, mp. $164{ }^{\circ} \mathrm{C} ;{ }^{1} \mathrm{H}$ NMR $(300 \mathrm{MHz}$,

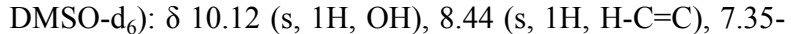
$7.44(\mathrm{~m}, 3 \mathrm{H}), 7.08(\mathrm{~d}, 7.5 \mathrm{~Hz}, 1 \mathrm{H})$; Anal. Calcd.for $\mathrm{C}_{10} \mathrm{H}_{6} \mathrm{~N}_{2} \mathrm{O}, \mathrm{C}, 70.58 ; \mathrm{H}, 3.55 ; \mathrm{N}, 16.46 \%$, found $\mathrm{C}, 70.24 ; \mathrm{H}$, $3.88 ; \mathrm{N}, 16.20 \%$.

2-(4-Benzoyloxyphenylmethylene) malononitrile (3n): Colorless crystal, Yield: $96 \%$, mp. $152{ }^{\circ} \mathrm{C}$; ${ }^{1} \mathrm{H}$ NMR $(300 \mathrm{MHz}$, $\left.\mathrm{CDCl}_{3}\right): \delta 8.20(\mathrm{~d}, 7.8 \mathrm{~Hz}, 2 \mathrm{H}), 8.01(\mathrm{~d}, 8.7 \mathrm{~Hz}, 2 \mathrm{H}), 7.78(\mathrm{~s}$, $1 \mathrm{H}, \mathrm{H}-\mathrm{C}=\mathrm{C}), 7.66-7.78(\mathrm{~m}, 1 \mathrm{H}), 7.54(\mathrm{t}, 7.5 \mathrm{~Hz}, 2 \mathrm{H}), 7.43(\mathrm{~d}$, $8.7 \mathrm{~Hz}, 2 \mathrm{H}) ;{ }^{13} \mathrm{C}$ NMR $\left(75 \mathrm{MHz}, \mathrm{CDCl}_{3}\right): \delta 82.54(=\mathrm{C}<)$, $112.49(\mathrm{CN}), 113.61(\mathrm{CN}), 123.12,128.41,128.53,128.75$, $130.29(-\mathrm{CH}=), 132.37,134.20,155.56,158.56,164.24$ (ester carbonyl); DEPT - 90 (75 MHz, $\left.\mathrm{CDCl}_{3}\right): 123.11,128.74$, $130.28,132.35,134.18,158.52$; DEPT - $135(75 \mathrm{MHz}$, $\left.\mathrm{CDCl}_{3}\right): 123.11,128.74,130.28,132.35,134.18,158.51$; Anal. Calcd. for $\mathrm{C}_{17} \mathrm{H}_{10} \mathrm{~N}_{2} \mathrm{O}_{2}, \mathrm{C}, 74.45 ; \mathrm{H}, 3.67 ; \mathrm{N}, 10.21 \%$, found $\mathrm{C}, 74.15 ; \mathrm{H}, 3.80 ; \mathrm{N}, 10.41 \%$.

2-(4-Benzoyloxy-3-methoxyphenylmethylene) malononitrile (3o): Colorless crystal, Yield: $98 \%$, mp. $140-141{ }^{\circ} \mathrm{C}$; ${ }^{1} \mathrm{H}$
NMR (300 MHz, $\left.\mathrm{CDCl}_{3}\right): \delta 8.20(\mathrm{~d}, 8.7 \mathrm{~Hz}, 2 \mathrm{H}), 7.76(\mathrm{~s}, 1 \mathrm{H}$, $\mathrm{H}-\mathrm{C}=\mathrm{C}), 7.74(\mathrm{~d}, 1.8 \mathrm{~Hz}, 1 \mathrm{H}), 7.64-7.69(\mathrm{~m}, 1 \mathrm{H}), 7.53(\mathrm{t}, 7.5$ $\mathrm{Hz}, 2 \mathrm{H}), 7.43$ (dd, 8.7 and $1.8 \mathrm{~Hz}, 1 \mathrm{H}), 7.34(\mathrm{~d}, 8.4 \mathrm{~Hz}, 1 \mathrm{H})$, 3.89 (s, 3H, OMe); Anal. Calcd. for $\mathrm{C}_{18} \mathrm{H}_{12} \mathrm{~N}_{2} \mathrm{O}_{3}, \mathrm{C}, 71.05 ; \mathrm{H}$, $3.97 ; \mathrm{N}, 9.21 \%$, found $\mathrm{C}, 70.89 ; \mathrm{H}, 4.04 ; \mathrm{N}, 9.45 \%$.

2-(3, 4-Methylenedioxyphenylmethylene) malononitrile (3p): Yellow crystal, Yield: 96\%, mp. $198{ }^{\circ} \mathrm{C} ;{ }^{1} \mathrm{H}$ NMR $(300 \mathrm{MHz}$, $\left.\mathrm{CDCl}_{3}\right): \delta 7.60(\mathrm{~s}, 1 \mathrm{H}), 7.59(\mathrm{~s}, 1 \mathrm{H}, \mathrm{H}-\mathrm{C}=\mathrm{C}), 7.32(\mathrm{dd}, 8.1$ and $1.5 \mathrm{~Hz}, 1 \mathrm{H}), 6.93(\mathrm{~d}, 8.1 \mathrm{~Hz}, 1 \mathrm{H}), 6.12(\mathrm{~s}, 2 \mathrm{H},-\mathrm{O}-\mathrm{CH} 2-$ O-); Anal. Calcd. for $\mathrm{C}_{11} \mathrm{H}_{6} \mathrm{~N}_{2} \mathrm{O}_{2}, \mathrm{C}, 66.67 ; \mathrm{H}, 3.05 ; \mathrm{N}$, $14.14 \%$, found $\mathrm{C}, 66.92 ; \mathrm{H}, 3.19 ; \mathrm{N}, 14.30 \%$.

2-(3-Indolylmethylene) malononitrile (3r): Yellow crystal, Yield: $82 \%$, mp. $170-172{ }^{\circ} \mathrm{C} ;{ }^{1} \mathrm{H}$ NMR $\left(300 \mathrm{MHz}, \mathrm{CDCl}_{3}\right): \delta$ 7.36-7.41 (m, 2H), $7.51(\mathrm{~d}, 8.7 \mathrm{~Hz}, 1 \mathrm{H}), 7.75(\mathrm{~d}, 8.4 \mathrm{~Hz}, 1 \mathrm{H})$, 8.11 (s, $1 \mathrm{H}, \mathrm{H}-\mathrm{C}=\mathrm{C}), 8.80(\mathrm{~d}, 3.3 \mathrm{~Hz}, 1 \mathrm{H}), 9.13$ (br. s, $1 \mathrm{H}$, $\mathrm{NH}$; Anal. Calcd. for $\mathrm{C}_{12} \mathrm{H}_{7} \mathrm{~N}_{3}, \mathrm{C}, 74.60 ; \mathrm{H}, 3.65 ; \mathrm{N}$, $21.75 \%$, found $\mathrm{C}, 74.43 ; \mathrm{H}, 3.78 ; \mathrm{N}, 21.88 \%$.

2-[\{p-3, 3'-Bis (2-methylindolyl) methyl\} phenylmethylene] malononitrile (3t): Pale-yellow crystal, Yield: $80 \%$, mp. 320 $322{ }^{\circ} \mathrm{C} ;{ }^{1} \mathrm{H}$ NMR $\left(300 \mathrm{MHz}, \mathrm{CDCl}_{3}\right): \delta 7.80$ (br. s, $2 \mathrm{H}, \mathrm{NH}$ ), $7.80(\mathrm{~d}, 8.7 \mathrm{~Hz}, 2 \mathrm{H}), 7.72(\mathrm{~s}, 1 \mathrm{H}, \mathrm{H}-\mathrm{C}=\mathrm{C}), 7.44(\mathrm{~d}, 8.1 \mathrm{~Hz}$, 2H), 7.28 (d, $9.0 \mathrm{~Hz}, 2 \mathrm{H}), 7.06$ (t, $6.9 \mathrm{~Hz}, 2 \mathrm{H}), 6.84-6.93(\mathrm{~m}$, 4H), 6.04 (s, 1H, Ar-CH), 2.09 (s, 6H, Me); Anal. Calcd. for $\mathrm{C}_{29} \mathrm{H}_{22} \mathrm{~N}_{4}, \mathrm{C}, 81.67 ; \mathrm{H}, 5.20 ; \mathrm{N}, 13.14 \%$, found $\mathrm{C}, 81.34 ; \mathrm{H}$, $5.41 ; \mathrm{N}, 13.27 \%$

p-Bis-2-(phenylmethylene) malononitrile (3w): White crystal, Yield: 98\%, mp. 298-300 ${ }^{\circ} \mathrm{C} ;{ }^{1} \mathrm{H}$ NMR $(300 \mathrm{MHz}$, DMSO$\left.\mathrm{d}_{6}\right): \delta 8.63(\mathrm{~s}, 2 \mathrm{H}, \mathrm{H}-\mathrm{C}=\mathrm{C}), 8.09(\mathrm{~s}, 4 \mathrm{H}) ;{ }^{13} \mathrm{C} \mathrm{NMR}(75 \mathrm{MHz}$, DMSO-d $\left._{6}\right): \delta 84.71(=\mathrm{C}<), 112.14(\mathrm{CN}), 113.80(\mathrm{CN})$, $130.83(-\mathrm{CH}=), 135.32$ (aromatic quaternary), 159.80 (aromatic $-\mathrm{CH}=)$; DEPT - 90 (75 MHz, DMSO-d $\left.{ }_{6}\right)$ : 130.83 , 159.81; DEPT - 135 (75 MHz, DMSO-d $\left.{ }_{6}\right): 130.84,159.81$; Anal. Calcd. for $\mathrm{C}_{14} \mathrm{H}_{6} \mathrm{~N}_{4}, \mathrm{C}, 73.04 ; \mathrm{H}, 2.63 ; \mathrm{N}, 24.34 \%$, found $\mathrm{C}, 72.98, \mathrm{H}, 2.76 ; \mathrm{N}, 24.46 \%$.

\section{Results and discussion}

In connection with our enduring interest concerning the investigation of new natural catalyst and development of new methodologies $[55-57,63]$ we report herein a highly efficient and economic Knoevenagel condensation using a cooperative effect of visible light and aqueous tamarind juice. The strategy was applied for the condensation of different aldehydes and malononitrile (Scheme 1).

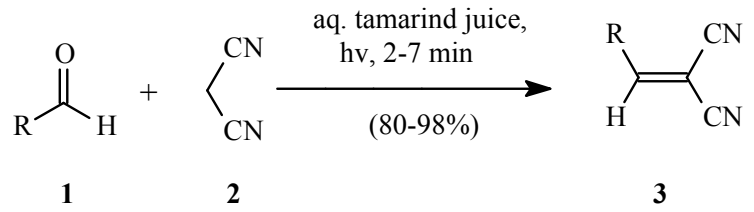

$\mathrm{R}=$ aryl, cinnamyl, heteroaryl, alkyl

(23 examples)

Scheme 1: Photochemical Knoevenagel condensation of malononitirile with aldehydes

In a preliminary study, 3-hydroxybenzaldehyde (1a) was treated with mamononitrile (2) (mole ratio 1:1) in presence of aqueous tamarind juice $(5 \mathrm{~mL}, \mathrm{pH}=3.0)$ under visible light. The reaction was found to be complete within 2 min affording 2-(3-hydroxyphenylmethylene) malononitrile (3a) in 94\% yield. Encouraged by this result, we carried out the reaction by a variation of conditions, the results of which are given in Table 1. It is evident from the result that the reaction gave best yield of the product when aqueous tamarind juice was used in $5 \mathrm{~mL}$ at $\mathrm{pH} 3.0$ under visible light. 
Table 1: Optimization of experimental condition for synthesis of $\mathbf{3 a}$

\begin{tabular}{|c|c|c|c|c|c|c|}
\hline Entry & $\begin{array}{l}\text { Aq. } \\
\text { tamarind } \\
\text { juice } \\
(\mathrm{mL})\end{array}$ & $\begin{array}{l}\text { Water } \\
(\mathrm{mL})\end{array}$ & $\begin{array}{l}\mathrm{pH} \text { of } \\
\text { the } \\
\text { solution }\end{array}$ & $\begin{array}{l}\text { Mode } \\
\text { of } \\
\text { reaction }\end{array}$ & $\begin{array}{l}\text { Reaction } \\
\text { time } \\
(\mathrm{min})\end{array}$ & $\begin{array}{l}\text { Yield } \\
(\%)\end{array}$ \\
\hline 1. & 5 & - & 3.0 & $\begin{array}{l}\text { visible } \\
\text { light }\end{array}$ & 2 & 94 \\
\hline 2. & 5 & - & 3.0 & $\begin{array}{l}\text { rt with } \\
\text { stirring }\end{array}$ & 10 & 60 \\
\hline 3. & 5 & - & 3.0 & reflux & 10 & 75 \\
\hline 4. & - & 5 & 7.0 & $\begin{array}{l}\text { visible } \\
\text { light }\end{array}$ & 10 & 40 \\
\hline 5. & - & 5 & 7.0 & $\begin{array}{l}\text { rt with } \\
\text { stirring }\end{array}$ & 60 & - \\
\hline 6. & - & 5 & 7.0 & reflux & 60 & 30 \\
\hline 7. & 5 & - & 4.5 & $\begin{array}{l}\text { visible } \\
\text { light }\end{array}$ & 2 & 70 \\
\hline 8. & 5 & - & 2.0 & $\begin{array}{l}\text { Visible } \\
\text { light }\end{array}$ & 2 & 85 \\
\hline 9. & 10 & - & 3.0 & $\begin{array}{l}\text { visible } \\
\text { light }\end{array}$ & 2 & 94 \\
\hline
\end{tabular}

Under the optimized condition, the generality of the process investigated with different aromatic and aliphatic aldehydes, and the results are summarized in Table 2. The light induced reactions were found to be very clean and the products were obtained in extremely pure crystalline states with an average yield of $80-98 \%$ and the reaction time varied on an average 2$7 \mathrm{~min}$. The products are isolated from the reaction mixture in pure crystalline form by cooling in an ice-bath and need no further crystallization for aromatic aldehydes. However, in case of aliphatic aldehydes for entries 21, 22 (Table 2) the products are oily liquid and obtained by chromatographic separation over silica gel and the results are given in Table 2 . The possibility of application of the presented method is demonstrated by using various substituted aromatic and aliphatic aldehydes to reacts with malononitrile. The procedure was successfully applied for heteroarotic (entries 18-20) and long-chian aliphatic aldehyde (entry 22). The ether (entries 3 , $9,15,16)$ and esters (entries 14, 15) linkages in the aromatic aldehydes were unaffected under photochemical conditions. The reaction was further explored for the synthesis of p-bis2 -(phenylidene) malononitrile in $98 \%$ yield by the condensation of terephthalaldehyde (entry 23) with two moles of malononitrile under similar reaction conditions.

In the present instance, we speculate that the reaction may plausibly be initiated by homolytic $\mathrm{C}-\mathrm{H}$ bond cleavage of malononitrile (2) in the presence of visible light to produce a radical $\mathbf{A}$ and hydrogen radical which is trapped immediately by water molecule to form radical B. Aldehyde (1) becomes activated by protonation from tamarind juice to produce a protonated species $\mathbf{C}$. One electron transfer from $\mathbf{B}$ to $\mathbf{D}$ produced a radical $\mathbf{E}$, which couples with radical $\mathbf{A}$ to form $\mathbf{F}$. Protonation of $\mathbf{F}$ followed by dehydration from $\mathbf{G}$ to form the title compound $\mathbf{3}$ as depicted in Scheme 2.

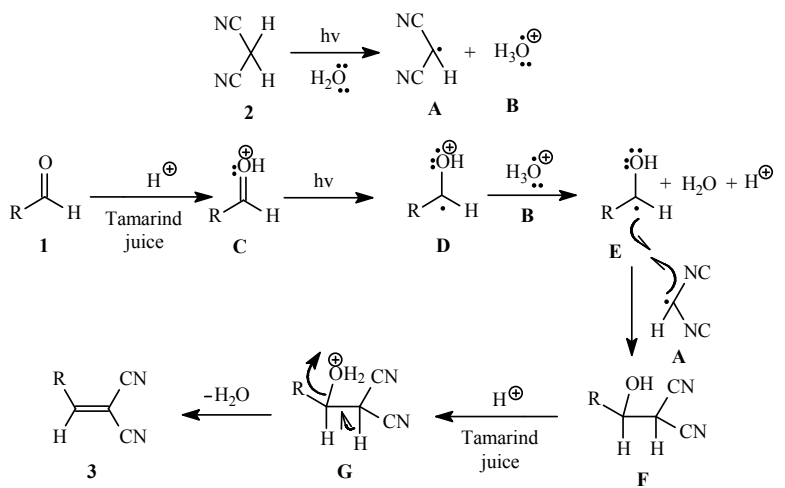

Scheme 2. Plausible mechanistic pathway for the photochemical Knoevenagel condensation of malononitrile and aldehydes catalyzed by aqueous tamarind juice.

\section{Conclusion}

We have established a potentially efficient, absolutely clean and high yielding eco-friendly methodology, for the light induced Knoevenagel condensation of various aromatic and aliphatic aldehydes with malononitrile using aqueous tamarind juice devoid of any toxic catalyst/solvents, solid support and surfactant and may be considered as an excellent improvement over the existing methods. All the products may act as a good dienophiles in Diels-Alder reactions and the products 3a, 3n-p, 3r, 3t, 3w are new compounds which may have potential biological activities.

\section{Acknowledgement}

This research was supported by the Minor Research Project(S) No. PSW-130/11-12 (ERO) by the University Grants Commission, New Delhi, India.

Table 2: Results of photochemical Knoevenagel condensation of malononitrile with aldehydes catalyzed by aqueous tamarind juice

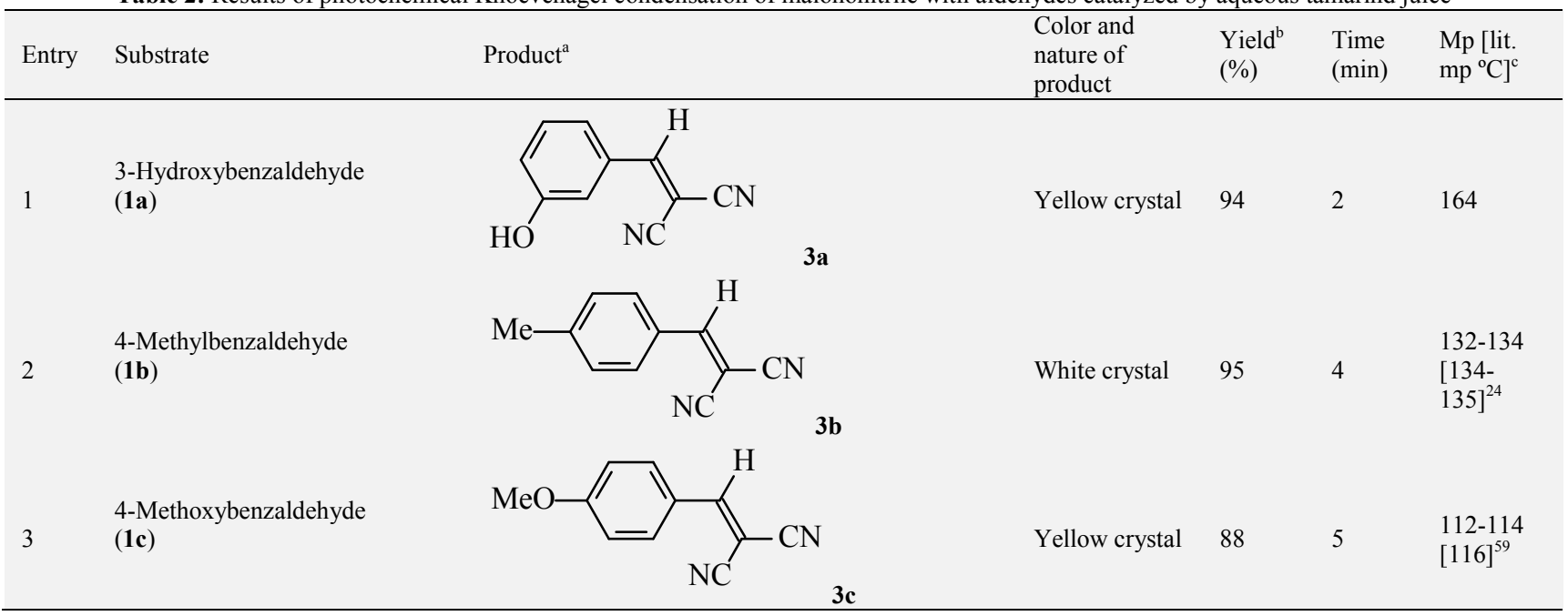


-Hydroxybenzaldehyde (1d)<smiles>N#CC(C#N)=Cc1ccccc1O</smiles>

Benzaldehyde

(1e)

4-Hydroxybenzaldehyde

6 (1f)<smiles>N#CC(C#N)=Cc1ccccc1</smiles>

Light brown crystal

Yellowish crystal

Colorless crystals

$3 g$<smiles>N#CC(C#N)=Cc1ccc(Br)cc1</smiles>

$3 h$

$9 \quad$ Vaniline

(1i)

4-N,N-Dimethylaminobenzaldehyde (1j)

4-Bromobenzaldehyde (1h)<smiles>N#CC(C#N)=Cc1ccc(Cl)cc1</smiles><smiles>COc1cc(C=C(C#N)C#N)ccc1O</smiles>
$3 \mathbf{i}$<smiles>CN(C)c1ccc(/C=C/C#N)cc1</smiles>

2-Nitrobenzaldehyde

11 (1k)<smiles>N#CC(C#N)=Cc1ccccc1[N+](=O)[O-]</smiles>

$3 \mathbf{k}$

12 3-Nitrobenzaldehyde (1I)<smiles>N#CC(C#N)=Cc1cccc([N+](=O)[O-])c1</smiles>
31<smiles>N#CC(C#N)=Cc1ccc([N+](=O)[O-])cc1</smiles>
$3 \mathrm{~m}$

4-Benzoyloxybenzaldehyde (1n)<smiles>N#CC(C#N)=Cc1ccc(OC(=O)c2ccccc2)cc1</smiles>

4-Benzoyloxy-3-

15

4-Nitrobenzaldehyde (1m)

\section{Pale-yellow} crystals

Colorless crystal

Colorless solid $\quad 98$

140-141 
16 Piperanal

(1p)

17

Cinnamaldehyde

(1q)

18

Indole-3-aldehyde

(1r)

19

Pyridine-3-aldehyde

(1s)

$p$-[3,3'-Bis $(2-$

20

methylindolyl)]methylbenzaldehyde)

(1t)

Acetaldehyde

(1u)

23

Terephthaldialdehyde (1w)<smiles>N#CC(C#N)=Cc1ccc2c(c1)OCO2</smiles>

3p<smiles>N#CC(C#N)=C/C=C/c1ccccc1</smiles><smiles>N#CC(C#N)=Cc1c[nH]c2ccccc12</smiles>

$3 q$<smiles>N#CC(C#N)=Cc1cccnc1</smiles>

$\mathrm{NC}$<smiles>Cc1[nH]c2ccccc2c1C1c2c([nH]c3ccccc23)Cc2[nH]c3ccccc3c21</smiles>

$3 t$<smiles>CC=C(C#N)C#N</smiles><smiles>CCCC=C(C#N)C#N</smiles>

3u

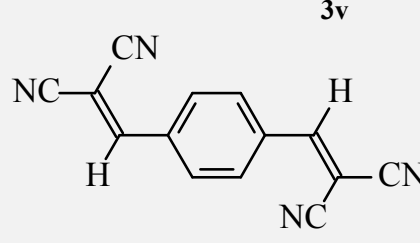

p

$3 \mathbf{r}$

3s
Yellowish crystals

96

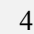

198

Yellow crys-

$\begin{array}{llll}\text { Yellow crys- } & 80 & 5 & {[127-} \\ \text { tals } & & & 129]^{30}\end{array}$

126-128

[127-

Yellow crys-

tals

$82 \quad 5$

170-172

White crystal

92

82-84

[84-85] ${ }^{24}$

Pale-yellow

crystal

320-322

Oily liquid

82

5

Liquid $^{16}$

Oily liquid

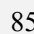

7

Liquid $^{16}$

White crystal

a) All products were identified by their physical and spectral data.

b) Yield refers to combined amounts of first and second crops of crystallized products obtained either directly or after chromatography.

c) Literature references of melting point.

\section{References}

[1] Knoevenagel E (1894) Uebereine darstellungsweise der glutarsaure Berichte der Deutschen Chemischen Gesellschaft 2(27):2345-2346.

[2] Knoevenagel E (1898) Condensationen zwisschen malonester und aldehyden unter dem einfluss von ammoniak und organischen aminen, Chemische Berichte 31(3): 2585-2595.

[3] Jones G (1967) The Knoevenagel condensation, Organic Reactions 15:204-599.
[4] Tietze LF \& Beifuss U (1991) The Knoevenagel reaction. In Comprehensive Organic Synthesis, Trost, BM, Ed. Pergamon Press: Oxford, UK, 341-394.

[5] Yu N, Aramini JM, Germann MW \& Huang Z (2000) Reactions of salicylaldehydes with alkyl cyanoacetates on the surface of solid catalysts: synthesis of $4 \mathrm{H}$-chromene derivatives, Tetrahedron Letters 41(36): 6993-6996.

[6] Gallos J, Discordia RP, Crispino GA, Li J, Grosso JA, Polniaszek V \& True VC (2003) A mild and efficient synthesis of 4-aryl-quinolin$2(1 \mathrm{H})$-ones via a tandem amidation/Knoevenagel condensation of 2amino-benzophenones with esters or lactones, Tetrahedron Letters 44(22): 4271-4273. 
[7] Xing C \& Zhu S (2004) unexpected formation of tetrasubstituted 2, 3 dihydrofurans from the reactions of $\beta$-keto polyfluoroalkanesulfones with aldehydes, Journal of Organic Chemistry 69(19): 6486-6488.

[8] Tietze LF \& Rackelmann N (2004) Domino reactions in the synthesis of heterocyclic natural products and analogs, Pure and Applied Chemistry 76(11): 1967-1983.

[9] Vijender M, Kishor P \& Satyanarayana B (2008) Zirconium tetrachloride-SiO2 catalyzed Knoevenagel condensation: A simple and efficient protocol for the synthesis of substituted electrophilic alkenes, Arkivoc xiii: $122-128$.

[10]Rao PS \& Venkataratnam RV (1991) Zinc chloride as a new catalyst for Knoevenagel condensation, Tetrahedron Letters 32(41): 58215822.

[11]Prajapati D \& Sandhu JS (1993) Cadmium iodide as a new catalyst for Knoevenagel condensation, Journal of the Chemical Society, Perkin Transactions 1, 1: 739-740.

[12]Lehnert, W. (1970) Verbesserte variante der Knoevenagelkondensation mit TiC14/THF/pyridine (I). alkyliden-und arylidenmalonester bei $0-25^{\circ} \mathrm{C}$, Tetrahedron Letters 11(54): 4723 4724.

[13]Dai G, Shi D, Zhou L \& Huaxue Y (1995) Knoevenagel condensation catalysed by potassium fluoride/alumina, Chinese Journal of Applied Chemistry 12(2): 104-108.

[14] Gill C, Pandhare G, Raut R, Gore V \& Gholap S (2008) Knoevenagel condensation: A simple and efficient protocol of electrophilic alkenes catalyzed by anhydrous ferric sulphate with remarkable reusability, Bulletin of the Catalysis Society of India 7: 153-157.

[15][Mogilaiah K \& Reddy CS (2003) an efficient Friedlander condensation using sodium fluoride as catalyst in the solid state, Synthetic Communications 33(18): 3131-3134.

[16] Mallouk S, Bougrin K, Laghzizil a \& Benhida R (2010) Microwaveassisted and efficient solvent-free Knoevenagel condensation. A sustainable protocol using calcium hydroxyapatite as catalyst, Molecules 15(2): 813-823.

[17]Bhuiyan MMH, Hossain MI, Ashraful M \& Mahmud MM (2012) Microwave assisted Knoevenagel condensation: Synthesis and antimicrobial activities of some arylidene-malononitriles, Chemistry Journal 2(1): 30-36.

[18] McNulty J, Steere JA \& Wolf S (1998) The ultrasound promoted Knoevenagel condensation of aromatic aldehydes, Tetrahedron Letters 39(44): 8013-8016.

[19]Palmisano G, Tibiletti F, Penoni A, Colombo F, Tollari S, Garella D, Tagliapietra S \& Cravotto G (2011) Ultrasound-enhanced one-pot synthesis of 3-(Het)arylmethyl-4-hydroxycoumarins in water, Ultrasonics Sonochemistry 18(2): 652-660.

[20]Pratap UR, Jawale DV, Waghmare RA, Lingampalle DL \& Mane RA (2011) Synthesis of 5-arylidene-2,4-thiazolidinediones by Knoevenagel condensation catalyzed by baker's yeast, New Journal of Chemistry 35(1): 49-51.

[21]Wang C, Guan Z \& He Y (2011) Biocatalytic domino reaction: synthesis of 2H-1-benzopyran-2-one derivatives using alkaline protease from Bacillus licheniformis, Green Chemistry 13(8): 2048-2054.

[22]Xia Y, Yang Z-Y, Brossi A \& Lee K-H (1999) Asymmetric solidphase synthesis of (3R,4R)-di-O-cis-acyl 3-carboxyl khellactones, Organic Letters 1(13): 2113-2115.

[23]Guo G, Arvanitis EA, Pottorf RS \& Player MP (2003) Solid-phase synthesis of a tyrphostin ether library, Journal of Combinatorial Chemistry 5(4): 408-413.

[24] Ying A-G, Liu L, Wu G-F, Chen X-Z, Ye W-D, Chen J-H \& Zhang K-Y (2009) Knoevenagel condensation catalyzed by DBU Bronsted ionic liquid without solvent, Chemical Research in Chinese Universities 25(6): 876-881.

[25] Khan FA, Dash FJ, Satapathy R \& Upadhyay SK (2004) Hydrotalcite catalysis in ionic medium: a recyclable reaction system for heterogeneous Knoevenagel and nitroaldol condensation, Tetrahedron Letters 45(15): 3055-3058

[26] Verdia P, Santamarta F \& Tojo E (2011) Knoevenagel reaction in [MMIm][MSO4]: synthesis of coumarins,Molecules 16(6): 4379-4388

[27]Bigi F, Conforti ML, Maggi R, Piccinno a \& Sartori G (2000) Clean synthesis in water: uncatalysed preparation of ylidenemalonitriles, Green Chemistry 2(3): 101-103.

[28] Wang S, Ren Z, Cao W \& Tong W (2001) The Knoevenagel condensation of aromatic aldehydes with malononitrile or ethyl cyanoacetate in the presence of CTMAB in water, Synthetic Communications 31(5): 673-677

[29] Oskooie HA, Heravi MM, Derikvand F, Khorasani M \& Bamoharram FF (2006) On water: An efficient Knoevenagel condensation using
12-Tungstophoric acid as a reusable green catalyst, Synthetic Communications 36(19): 2819-2823.

[30]Pasha MA \& Manjula K (2011) Lithium hydroxide: A simple and an efficient catalyst for Knoevenagel condensation under solvent-free grindstone method, Journal of Saudi Chemical Society 15(3): 283-286.

[31]Rong L, Li X, Wang H, Shi D, Tu S \& Zhuang Q (2006) Efficient green procedure for the Knoevenagel condensation under solvent-free conditions, Synthetic Communications 36(16): 2407-2412.

[32]Ren Z, Cao W \& Tong W (2002) The Knoevenagel condensation reaction of aromatic aldehydes with malononitrile by grinding in the absence of solvents and catalysts, Synthetic Communications 32(22): 3475-3479.

[33]Okkerse C \& Bekkun V (1999) from fossil to green, Green Chemistry 1(2): 107-114.

[34]Anastas PT \& Warner JC (2000) Green Chemistry: Theory and Practice, Oxford University Press, New York, USA.

[35]Hoffmann N (2008) photochemical reactions as key steps in organic synthesis, Chemical Reviews 108(3): 1052-1103.

[36]Fagnoni M, Dondi D, Ravelli D \& Albini A (2007) Photocatalysis for the formation of the C-C bond, Chemical Reviews 107(6): 2725-2756.

[37]Ghosh S \& Das J (2011) A novel photochemical wittig reaction for the synthesis of 2-aryl/alkylbenzofurans, Tetrahedron Letters 52(10): 1112-1116.

[38]Ghosh S, Das J \& Chattopadhyay S (2011) A novel light induced Knoevenagel condensation of Meldrum's acid with aromatic aldehydes in aqueous ethanol, Tetrahedron Letters 52(22): 2869-2872.

[39]Ghosh, S, Das J \& Saikh F (2012) A new synthesis of 2aryl/alkylbenzofurans by visible light stimulated intermolecular sonogashira coupling and cyclization reaction in water, Tetrahedron Letters 53(44): 5883-5886.

[40]Ghosh S, Saikh F, Das J \& Pramanik AK (2013) Hantzsch 1,4dihydropyridine synthesis in aqueous ethanol by visible light, Tetrahedron Letters 54(1): 58-62.

[41]Li C \& Chen L (2006) Organic chemistry in water, Chemical Society Reviews 35(1): 68-82.

[42]Breslow R (1991) hydrophobic effects on simple organic reactions in water, Accounts of Chemical Research 24(6): 159-164.

[43]Ramesh E \& Raghunathan R (2009) Microwave-assisted K-10 montmorillonite clay-mediated Knoevenagel hetero-Diels-Alder reactions: A novel protocol for the synthesis of polycyclic pyrano[2,3,4kl]xanthenes derivatives, Synthetic Communications 39(4): 613-625.

[44]Habibi D \& Marvi O (2006) Montmorillonite KSF and Montmorillonite K-10 clays as efficient catalysts for the solventless synthesis of bismaleimides and bisphthalimides using microwave irradiation, Arkivoc xiii: 8-15.

[45] Chakrabarty M, Mukherjee A, Arima S, Harigaya Y \& Pilet G (2009) Expeditious reaction of ninhydrin with active methylene compounds on montmorillonite K 10 clay, Monatshefte Fur Chemie 140(2): 189197.

[46] Wada S \& Suzuki H (2003) Calcite and fluorite as catalyst for the Knoevenagel condensation of malononitrile and methyl cyanoacetate under solvent-free conditions, Tetrahedron Letters 44(2): 399-401.

[47]Zahouily M, Mounir B, Charki H, Mezdar A, Bahlaouan B \& Ouammou M (2006) Investigation of the basis catalytic activity of natural phosphates in the Michael condensation, Arkivoc xiii: 178-186.

[48]Zahouily M, Bahlaouan B, Rayadh A \& Sebti S (2004) Natural phosphates and potassium fluoride doped natural phosphate: efficient catalyst for the construction of a carbon-nitrogen bond, Tetrahedron Letters 45(21): 4135-4138.

[49]Sebti S, Smahi A \& Solly A (2002) Natural phosphate doped with potasiuum fluoride and modified with sodium nitrate: efficient catalysts for the Knoevenagel condensation, Tetrahedron Letters 43(10): 1813-1815.

[50]Riadi Y, Mamouni R, Azzalou R, Boulahjar R, Abrouki Y, Haddad ME, Routier S, Guillaumet G \& Lazar S (2010) Animal bone meal as an efficient catalyst for crossed-aldol condensation, Tetrahedron Letters 51(51): 6715-6717.

[51]Deshmukh MB, Patil SS, Jadhav SD \& Pawar PB (2012) Green approach for Knoevenagel condensation of aromatic aldehydes with active methylene group, Synthetic Communications 42(8): 1177-1183.

[52]Patil S, Jadhav SD \& Deshmuk MB (2011) Natural acid catalyzed multi-component reaction as a green approach, Archives Apllied Science Research 3(1): 203-208.

[53] Sachdeva H, Saroj R, Khaturia S \& Dwivedi D (2013) Environeconomic synthesis and characterization of some new 1,2,4-triazole derivative as organic fluorescent materials and potent fungicidal agents, Organic Chemistry International Article ID 659107: 19 pages. 
[54] Patil S, Jhadav SD \& Patil UP (2012) Natural acid catalyzed synthesis of Schiff base under solvent-free condition: As a green approach, Archives of Apllied Science Research 4(2): 1074-1078.

[55]Pal R, Khasnobis S \& Sarkar T (2013) First application of fruit juice of Citrus limon for facile and green synthesis of bis- and tris(indolyl)methanes in water, Chemistry Journal 3(1): 7-12.

[56]Pal R (2013) Microwave-assisted eco-friendly synthesis of bistris(indolyl)methanes and synthesis of di-bis(indolyl)methanes catalyzed by fruit juice of Citrus limon under solvent-free conditions, IOSR Journal of Applied Chemistry 3(4): 1-8.

[57]Pal R (2013) New greener alternative for biocondensation of aldehydes and indoles using lemon juice: Formation of bis-, tris-, ans tetraindoles, International Journal of Organic Chemistry 3(2): 136-142.

[58] Patil S, Jadhav SD \& Mane S (2011) Pineapple juice as a natural catalyst: An excellent catalyst for biginelli reaction, Journal of Organic Chemistry 1(3): 125-131.

[59]Patil S, Jadhav SD \& Deshmukh MB (2013) Eco-friendly and economic method for Knoevenagel condensation by employing natural catalyst, Indian Journal of Chemistry, Section B 52(8): 1172-1175.

[60]Fonseca AM, Monte FJ, Oliveira MCF, Mattos MCM, Cordell GA, Braz-Filho R \& Lemos TLG (2009) Coconut water (Cocos nucifera L.) -A new biocatalyst system for organic synthesis, Journal of Molecular Catalysis B: Enzymatic 57(1-4): 78-82.

[61] Mote K, Pore S, Rashinkar G, Kambale S, Kumbhar A \& Salunkhe R (2010) Acacia concinna pods: as a green catalyst for highly efficient synthesis of acylation of amines, Archives of Apllied Science Research 2(3): 74-80.

[62]Pore S, Rashimkar G, Mote K \& Salunkhe R (2010) Aqueous extract of the pericarp of sapindus trifoliatus fruits: A novel green catalyst for the aldimine synthesis, Chemistry \& Biodiversity 7(7): 1796-1800.

[63] Pal R (2013) A convenient, rapid and eco-friendly synthesis of bis-, tris(indolyl)methanes and synthesis of tetraindolyl compounds catalyzed by tamarind juice under microwave irradiation, International Journal of Chemtech Applications 2(3): 26-40.

[64]El-Siddig K, Gunasena HPM, Prasad BA, Pushpakumara DKNG, Ramana KVR, Vijayanand P \& Wllliams JT (2006) Fruits for the future 1- Tamarind, Tamarindus indica; Southampton Centre for Underutilised Crops, UK:17-18. 